\title{
MODELLING THE INNOVATION ACTIVITY OF AN ENTERPRISE
}

\author{
V.G. Mokhov, South Ural State University, Chelyabinsk, Russian Federation, \\ mokhov50@mail.ru, \\ K.S. Stakhanov, South Ural State University, Chelyabinsk, Russian Federation, \\ kiril.stakhanov@gmail.com
}

\begin{abstract}
Specific features of foresight expert forecasting methods make them ineffective for compresided analysis of enterprise innovation activity. This determined the urgency of developing a deterministic method for predicting the results of innovative activities of the corporation resulting from the simulation of production indicators.

The paper considers modelling of innovation process quantitative characteristics, aimed at the industrial enterprises innovative activity evaluation under implementation of a specific investment project. In the process of modelling operations used a production function. To account for the specificity of industrial production basic production function modified with regard to material resources and influence of "autonomous" technical progress is Hicksneutral. The developed algorithm of solution the Mendershausen multicollinearity effect. Credibility built industrial plant test confirmed by the consent of the criteria of operational models.

The author's method of estimation of innovative activity of industrial enterprises in implementation of innovation project on the basis of dynamics of indicators of the elasticity of production. The proposed method allows to reflect the economic result from the introduction of a specific innovation project. The research results are recommended for practical use in the selection of investment projects and for integrated assessment of corporate governance through the additional key performance indicator.

Keywords: economic and mathematical model of an industrial production; corporate foresight; production function; innovation activity evaluation.
\end{abstract}

Introduction. Foresight is a set of expert methods used to predict innovation activity results [1]. Foresight researches come from the assumption that there are many options for the future, and the likelihood of one of them depends on the actions that are taken at the current time. In addition, the introduction of a new product or innovation process has no required amount of historical data for the extrapolation models, which could describe the behavior of firms in the market as a result of the innovative project. Thus, the specific features of expert forecasting methods make them ineffective for the comprehensive analysis of innovative companies and encourage researchers to seek additional analytical tools.

Despite the fact that at the moment there is no effective method-term describing the use of quantitative methods to predict the results of innovative activity of the enterprise, it is possible to quantify these results. This determined the relevance of developing a method of predicting the results of the corporation innovative activities on the basis of modelling the resulting production figures.

1. Modelling the Organization's Activity. The initial stage of the prediction is the Cobb - Douglas production function calculations:

$$
C P=A \cdot N^{\alpha} \cdot F A^{\beta},
$$


where CP (commercial product) means commercial output, measured in thousand rubles per year; $\mathrm{N}$ is a staff size, measured in employees; FA (fixed assets) is the amount of basic production assets turnover, measured in thousand rubles per year; A represents an empirical coefficient which conjugates the function composite elements (right and left parts) and equally performs a scaled coefficient of reduction for each composite element (1), $\alpha, \beta$ are the numerical output elasticities of the correspondent assets and the output.

For material-intensive production enterprises, it is advisable to take into calculation physical resources used at production output. "Autonomous" technical progress Hicksneutral also must be taken into consideration, adding a multiplier. As a result, the function takes the form:

$$
C P=A \cdot N^{\alpha} \cdot F A^{\beta} \cdot C A^{\gamma} \cdot e^{\lambda t}
$$

where CA are the current assets, measured in thousand rubles per year, $\gamma$ is the output elasticity upon current assets, numerical; $e$ is the base of the natural logarithm; $\lambda$ is the coefficient of elasticity, showing the effect of "autonomous" technical progress on production results, numerical; $t$ is the time valuated relatively to the base year, year, $\left(t_{i}=T_{i}-T_{b}\right)$.

The production function parameters $A, \alpha, \beta, \gamma, \lambda$ based on historical data $C P, N, F A$, $C A, t$ can be represented in its standard form by solving the system of equations

$$
\left\{\begin{array}{l}
\sum_{i=1}^{m} \ln C P_{i}=m \cdot \ln A+\alpha \cdot \sum_{i=1}^{m} \ln N_{i}+\beta \cdot \sum_{i=1}^{m} F A_{i}+\gamma \cdot \sum_{i=1}^{m} \ln C A_{i}+ \\
+\lambda \cdot \sum_{i=1}^{m} t_{i}, \\
\sum_{i=1}^{m}\left(\ln C P_{i} \cdot \ln N_{i}\right)=\ln A \cdot \sum_{i=1}^{m} \ln N_{i}+\alpha \cdot \sum_{i=1}^{m}\left(\ln N_{i}\right)^{2}+ \\
+\beta \cdot \sum_{i=1}^{m}\left(\ln F A_{i} \cdot \ln N_{i}\right)+\gamma \cdot \sum_{i=1}^{m}\left(\ln C A_{i} \cdot \ln N_{i}\right)+\lambda \cdot \sum_{i=1}^{m}\left(t_{i} \cdot \ln N_{i}\right), \\
\sum_{i=1}^{m}\left(\ln C P_{i} \cdot \ln F A_{i}\right)=\ln A \cdot \sum_{i=1}^{m} \ln F A_{i}+\alpha \cdot \sum_{i=1}^{m}\left(\ln F A_{i} \cdot \ln N_{i}\right)+ \\
+\beta \cdot \sum_{i=1}^{m}\left(\ln F A_{i}\right)^{2}+\gamma \cdot \sum_{i=1}^{m}\left(\ln F A_{i} \cdot \ln C A_{i}\right)+\lambda \cdot \sum_{i=1}^{m}\left(t_{i} \cdot \ln F A_{i}\right), \\
\sum_{i=1}^{m}\left(\ln C P_{i} \cdot \ln C A_{i}\right)=\ln A \cdot \sum_{i=1}^{m} \ln C A_{i}+\alpha \cdot \sum_{i=1}^{m}\left(\ln C A_{i} \cdot \ln N_{i}\right)+ \\
+\beta \cdot \sum_{i=1}^{m}\left(\ln C A_{i} \cdot \ln F A_{i}\right)+\gamma \cdot \sum_{i=1}^{m}\left(\ln C A_{i}\right)^{2}+\lambda \cdot \sum_{i=1}^{m}\left(t_{i} \cdot \ln C A_{i}\right), \\
\sum_{i=1}^{m}\left(\ln C P_{i} \cdot t_{i}\right)=\ln A \cdot \sum_{i=1}^{m} t_{i}+\alpha \cdot \sum_{i=1}^{m}\left(t_{i} \cdot \ln N_{i}\right)+ \\
+\beta \cdot \sum_{i=1}^{m}\left(t_{i} \cdot \ln F A_{i}\right)+\gamma \cdot \sum_{i=1}^{m}\left(t_{i} \cdot \ln C A_{i}\right)+\lambda \cdot \sum_{i=1}^{m}\left(t_{i}\right)^{2}
\end{array}\right.
$$

where $m$ is a time frame of the historical data used $(m>4)$.

Parameters of production functions $A, \alpha, \beta, \gamma, \lambda$ in more general form can be found on the basis of the retrospective data on $C P, N, F A, C A, t$, by means of solving system if equations (3). In the system of equations (3) $m$ means the number of years, which it took to collect the retrospective data $(m>4)$.

If system (3) has no solution due to Mendershausen multicollinearity effect, it is recommended to do the following: divide the total differential of function (2) by the 
function $C P$ :

$$
d C P / C P=\alpha \cdot d N / N+\beta \cdot d F A / F A+\gamma \cdot d C A / C A+\lambda \cdot d t .
$$

Then the following nomenclatures are used:

$$
\begin{gathered}
\frac{d C P}{C P}=2 \cdot \frac{C P_{i+1}-C P_{i}}{C P_{i+1}+C P_{i}}=z, \frac{d N}{N}=2 \cdot \frac{N_{i+1}-N_{i}}{N_{i+1}+N_{i}}=x, d t=t_{i+1}-t_{i}=1, \\
\frac{d F A}{F A}=2 \cdot \frac{F A_{i+1}-F A_{i}}{F A_{i+1}+F A_{i}}=y, \frac{d C A}{C A}=2 \cdot \frac{C A_{i+1}-C A_{i}}{C A_{i+1}+C A_{i}}=w .
\end{gathered}
$$

Expression (4) transforms into the equation:

$$
z=\alpha \cdot x+\beta \cdot y+\gamma \cdot w+\lambda .
$$

Then the elasticity coefficients $\alpha, \beta, \gamma, \lambda$ are calculated on the bases of the transformed source data of the system

$$
\left\{\begin{array}{l}
\sum_{i=1}^{m} z_{i}=\lambda \cdot m+\alpha \cdot \sum_{i=1}^{m} x_{i}+\beta \cdot \sum_{i=1}^{m} y_{i}+\gamma \cdot \sum_{i=1}^{m} w_{i} \\
\sum_{i=1}^{m}\left(x_{i} \cdot z_{i}\right)=\lambda \cdot \sum_{i=1}^{m} x_{i}+\alpha \cdot \sum_{i=1}^{m}\left(x_{i}\right)^{2}+\beta \cdot \sum_{i=1}^{m}\left(x_{i} \cdot y_{i}\right)+\gamma \cdot \sum_{i=1}^{m}\left(x_{i} \cdot w_{i}\right), \\
\sum_{i=1}^{m}\left(y_{i} \cdot z_{i}\right)=\lambda \cdot \sum_{i=1}^{m}\left(t_{i} \cdot y_{i}\right)+\alpha \cdot \sum_{i=1}^{m}\left(x_{i} \cdot y_{i}\right)+\beta \cdot \sum_{i=1}^{m}\left(y_{i}\right)^{2}+\gamma \cdot \sum_{i=1}^{m}\left(y_{i} \cdot w_{i}\right), \\
\sum_{i=1}^{m}\left(w_{i} \cdot z_{i}\right)=\lambda \cdot \sum_{i=1}^{m}\left(w_{i}\right)+\alpha \cdot \sum_{i=1}^{m}\left(w_{i} \cdot x_{i}\right)+\beta \cdot \sum_{i=1}^{m}\left(y_{i} \cdot w_{i}\right)+\gamma \cdot \sum_{i=1}^{m}\left(w_{i}\right)^{2} .
\end{array}\right.
$$

According to the elasticity coefficients' numerical values, the coefficient A is calculated by

$$
A=\frac{\sum_{i=1}^{m} z_{i} \cdot x_{i}^{\alpha} \cdot y_{i}^{\beta} \cdot w_{i}^{\gamma} \cdot e^{\lambda t}}{\sum_{i=1}^{m}\left(x_{i}^{\alpha} \cdot y_{i}^{\beta} \cdot w_{i}^{\gamma} \cdot e^{\lambda t}\right)^{2}} .
$$

The validity is checked analytically by goodness-of-fit test by Fisher, Student, Kolmogorov - Smirnov (KS-test).

The external environment of an organization is extremely aggressive and quite unpredictable under present instable economic and political conditions. In this context any innovative project implementation and investment is at risk and is quite difficult to perform. However, this is the moment when large-scale structural changes are to be carried out. The changes should deal with active innovative technologies and products implementation together with imports phase-out and lame duck industries development. The overall economic system conditions are impossible to change without active implementations, that is why economic and mathematical models of enterprises innovation activity should become an effective management tool.

2. Model of Enterprise's Innovation Activity Analysis. There are two models in order to evaluate the innovation activity of an industrial enterprise. The first one deals with the period of 5 years before the innovation project implementation. The second one deals with the period of 5 years after having executed the project. The difference of the production final rates $\triangle C P_{i}=C P_{i}-C P_{i+1}$ represents the particular innovation project 
execution. Innovational activity of an enterprise (IA), considered within the frames of the particular innovational project is evaluated according to the sum of dynamics of production elasticity within the review production period: $I A=\left(\alpha_{i+1}-\alpha_{i}\right)+\left(\beta_{i+1}-\beta_{i}\right)+\left(\gamma_{i+1}-\right.$ $\left.\gamma_{i}\right)+\left(\lambda_{i+1}-\lambda_{i}\right)$.

The proposed method can be used as one of the components of the integrated evaluation of the effectiveness of corporate governance. Assessing the impact of an innovative project on the operating results of the company allows to draw a conclusion about how faithful were selected organization's management strategy and key areas of development, how to invest money effectively for business owners. Accordingly, the level of innovation activity of the company may be included in the system of key performance indicators used at the facility.

Conclusions. 1. The foresight methods are not sufficient for objective and reliable evaluation of an industrial enterprises innovative activity. Such evaluation requires formal methods of modelling and predicting.

2. The Cobb - Douglas production function with provision for autonomous technical progress, Hicks-neutral, is the best tool to reflect the interdependence between the industrial enterprise resources' provision and the final rates.

3. The enterprise innovative activity for this investment project is evaluated by sum of dynamics of production elasticity within the review production period.

\title{
References
}

1. International scientific and educational Foresight-center HSE ISSEK. Available at: http://foresight.hse.ru (accessed 6 January 2016).

2. Flatau P. Hicks's The Theory of Wages: Its Place in the History of Neoclassical Distribution Theory. History of Economics Review. $65 \mathrm{p}$.

Received January 6, 2016

\section{МОДЕЛИРОВАНИЕ ИННОВАЦИОННОЙ АКТИВНОСТИ ПРЕДПРИЯТИЯ}

\author{
В.Г. Мохов, К.С. Стаханов
}

\begin{abstract}
Специфичные черты экспертных форсайт методов прогнозирования делают их недостаточно эффективными для всестороннего анализа инновационной активности предприятия. Это предопределило актуальность разработки детерминированного метода прогнозирования результатов инновационной деятельности корпорации на основе моделирования результирующих показателей производства.
\end{abstract}


Статья посвящена моделированию количественных характеристик инновационного процесса для оценки инновационной активности промышленного предприятия в контексте внедрения конкретного инвестиционного проекта. В процессе моделирования операционной деятельности предприятия использована производственная функция. Для учета специфики промышленного производства базовая производственная функция модифицирована с учетом материальных ресурсов и влияния «автономного» технического прогресса нейтрального по Хиксу. Предложен алгоритм решения проблемы эффекта мультиколлинеарности Мендерсхаузена. Достоверность построенных моделей операционной деятельности промышленного предприятия подтверждается проверкой по критериям согласия.

Предложен авторский метод оценки инновационной активности промышленного предприятия при внедрении инновационного проекта на основе динамики показателей эластичности производства. Предложенный метод позволяет отразить экономический результат от внедрения конкретного инновационного проекта.

Результаты исследования рекомендуются к практическому использованию при отборе инвестиционных проектов и для интегрированной оценки корпоративного управления через дополнительный ключевой показатель эффективности.

Ключевые слова: экономико-математическая модель промышленного производства; корпоративный форсайт; производственная функция; оценка инновационной активности.

\section{Литература}

1. Международный научно-образовательный Форсайт-центр ИСИЭЗ НИУ BШЭ. - URL: http://foresight.hse.ru (дата обращения 06.01.2016)

2. Flatau, P. Hicks's The Theory of Wages: Its Place in the History of Neoclassical Distribution Theory / P. Flatau // History of Economics Review. - 65 p.

Вениамин Геннадьевич Мохов, доктор экономических наук, профессор, кафедра «Предпринимательство и менеджмент», Южно-Уральский государственный университет (г. Челябинск, Российская Федерация), mokhov50@mail.ru.

Кирилл Станиславович Стаханов, аспирант, кафедра «Предпринимательство и менеджмент», Южно-Уральский государственный университет (г. Челябинск, Российская Федерация), kiril.stakhanov@gmail.com.

Поступила в редакиию 6 января 2016 г. 